\title{
Survival of Shiga toxin-producing Escherichia coli O157:H7 in Minas frescal cheese
}

\author{
Jesieli Braz FROZI ${ }^{1}$, Josiane Roberto DOMINGUES ${ }^{1}$, Luciana Maria Ramires ESPER ${ }^{1}$, \\ Joel Maurício Corrêa da ROSA², Ana Luiza Sant'Anna da Costa SILVA , Alice Gonçalves Martins GONZALEZ ${ }^{1 *}$
}

\begin{abstract}
Shiga toxin-producing Escherichia coli (STEC) O157:H7 strains (isolated by cattle's faeces and a reference strain, EDL933), were inoculated into pasteurized milk $\left(10^{2}\right.$ and $10^{3}$ cells. $\left.\mathrm{mL}^{-1}\right)$ to prepare the Minas frescal cheese. As control was used uninfected milk. Physicochemical and microbiological analyses were performed to milk and elaborated cheese. The O157:H7 strains were quantified in the stages of cheese processing and during $0,2,4,5,7,10$ and 15 storage days at $8{ }^{\circ} \mathrm{C}$ onto Sorbitol MacConkey Agar supplemented with potassium tellurite and cefixime (CT-SMAC). O157:H7 was not present in the pasteurised milk prior to the artificial inoculation. At the end of the processing the cheese had 10 to 100 times more STEC O157:H7 than the initial inoculum. During the storage, the Minas frescal cheese exhibited the largest population increase on the 4th and 5th day when inoculated with $10^{2}$ and $10^{3}$ cells. $\mathrm{mL}^{-1}$, respectively. Additionally, viable cells were found up to the 10th and 15th day, according to the amount of initial inoculum. This number of cells is able to cause infection in humans, and therefore, Minas frescal cheese, even when stored under refrigeration, is a potential vehicle of disease caused by STEC O157:H7.
\end{abstract}

Keywords: cheese; psychrotrophic bacteria; foodborne disease.

Practical Application: This study demonstrates that the Minas frescal cheese may be an important vehicle for STEC O157:H7, since this microorganism remains viable in this food for a long period even under refrigeration. In this study we can observe the psychrotrophic behavior of STEC O157:H7 in this rich food which is Minas frescal cheese.

\section{Introduction}

O157:H7 is a particularly virulent serotype of Shiga toxinproducing Escherichia coli (STEC), recognised as a human pathogen in 1982 (Riley et al., 1983). STEC O157:H7 has been considered to be a threat to public health in many countries because it has been involved in many outbreaks and caused a variety of diseases, such as haemorrhagic colitis, haemolytic uremic syndrome (HUS) and thrombotic thrombocytopenic purpura. Complications from these diseases can lead to death, especially in children, elderly patients and immunocompromised patients (Centers for Disease Control and Prevention, 2000). In Brazil, there is no systematic surveillance system for infection with STEC O157:H7 and HUS cases. However, research conducted in Brazil has demonstrated the occurrence of important STEC serotypes in human diseases, such as bloody diarrhoea, haemolytic anaemia and HUS (Guth et al., 2002; Souza et al., 2011).

STEC O157:H7 naturally colonises the gastrointestinal tract and recto-anal junction of cattle, which are the main reservoir of STEC, and these animals are generally asymptomatic (Lim et al., 2007). Many outbreaks caused by this pathogen are associated with the consumption of foods from bovine origin, as well as food and water that may have come into contact with the animal or its faeces (Centers for Disease Control and Prevention, 2000). Pasteurised milk and other dairy products, including cheese, have been associated with disease outbreaks in which the aetiological agent is STEC O157:H7 (Goh et al., 2002).

Due to the severity of the disease, the high potential for contamination, and the large-scale outbreaks caused by food contaminated by STEC O157:H7, studies have been undertaken to evaluate the behaviour and the viability of this pathogen in foods ready for consumption and during manufacturing (D’Amico et al., 2010; Breidt Junior \& Caldwell, 2011).

In Brazil, cheese is one of the most important products in the dairy industry, particularly the MFC. MFC is characterised as a fresh cheese obtained by enzymatic coagulation of milk with rennet and/or other suitable coagulating enzymes, supplemented or not with specific lactic bacteria. This is semihard cheese, very high humidity, to be eaten fresh (Brasil, 1997, 2004). The physico-chemical characteristics of this cheese increase the potential risk of its contamination with certain pathogens because it constitutes a suitable medium for their growth. Therefore, it is of great importance to assess the behaviour and the viability of STEC O157:H7 during the processing and storage of MFC produced from artificially contaminated pasteurised milk. The objectives of this study were, to evaluate the behaviour and the viability of two strains of STEC belonging to serotype O157:H7 during the processing of MFC and its storage at $8{ }^{\circ} \mathrm{C}$. 


\section{Materials and methods}

\subsection{Raw material}

The pasteurized milk (3\% of fat) was used as raw material for MFC production. The pasteurized milk was subjected to analyses for the verification of some of the minimum requirements for physicochemical and microbiological properties described in Brazilian law (Brasil, 2011). All analyses were performed in duplicate. The total acid concentration of the sample was measured by volumetric neutralisation. The results were expressed as the percentage of lactic acid (Brasil, 2006). The presence of antibiotic residues was investigated by Kit Eclipse 50 (Cap-lab ${ }^{\circledR}$, São Paulo, Brazil).

Twenty-five $\mathrm{mL}$ of milk samples were homogenised in $225 \mathrm{~mL}$ of buffered peptone water to $1 \%(\mathrm{w} / \mathrm{v})(\mathrm{BPW})$. Serial dilutions were performed for the enumeration of $E$. coli in Petrifilm $^{\text {TM }}$ EC (3M Company, St. Paul, EUA) according to the manufacturer's recommendations. Salmonella was investigated as described by APHA (American Public Health Association, 2001). The presence of E. coli O157:H7 was also investigated to ensure the absence of these microorganisms prior to the artificial contamination of the cheese. After enrichment for $3 \mathrm{~h}$ at $35^{\circ} \mathrm{C}, 100 \mu \mathrm{L}$ of the homogenate in BPW was seeded onto Sorbitol MacConkey Agar (SMAC; Himedia, Mumbai, India) supplemented with potassium tellurite $\left(2.5 \mathrm{mg} . \mathrm{L}^{-1}\right)$ and cefixime (0.05 mg.L $\mathrm{L}^{-1}$ ) (CT-SMAC) (Zadik et al., 1993) and incubated at $35^{\circ} \mathrm{C}$ for 24 to $48 \mathrm{~h}$.

\subsection{Bacterial strains}

Were used two strains of STEC O157:H7 separately: RJ581, which has genetic virulence markers specific to the pathogenic group of STEC and was isolated by cattle's faeces from Rio de Janeiro, Brazil (data unpublished), and a reference strain, EDL933 (ATCC 43495), which was isolated from ground beef involved in an outbreak in a chain of fast food restaurants in Michigan, USA.

\subsection{Milk artificial contamination}

A loop $(\sim 10 \mu \mathrm{L})$ of each bacterial strain was transferred to $5 \mathrm{~mL}$ of Trypticase Soy Broth (Himedia) at $35^{\circ} \mathrm{C}$ for 18 to $20 \mathrm{~h}$. The concentration of the culture was adjusted to $10^{8}$ cells. $\mathrm{mL}^{-1}$ based on the optical density (OD) measured by a spectrophotometer (UV-2600; Shimadzu, Tokyo, Japan) at a wavelength of $600 \mathrm{~nm}$, and serial dilutions were performed to contaminate different batches of milk with $10^{2}$ and $10^{3}$ STEC O157:H7 cells. $\mathrm{mL}^{-1}$. The different contaminated batches, as well as uninfected milk (negative control), were used for the preparation of cheese.

\subsection{Minas frescal cheese manufacture}

The cheeses were prepared from four group of milk samples (L1, L2, L3 and L4) of the same brand (Table 1). The milk was heated to $35^{\circ} \mathrm{C}$, and $200 \mathrm{ppm}$ of $\mathrm{CaCl}_{2}$ and $0.0625 \mathrm{~g}$. $\mathrm{L}^{-1}$ of rennet Halamix were added (Chr. Hansen A/S, Horsholm, Denmark). The temperature was maintained at $35^{\circ} \mathrm{C}$, and the coagulation process lasted for approximately $40 \mathrm{~min}$. After coagulation,
Table 1. Samples of Minas frescal cheese (MFC) according to the bacterial strain used, artificial initial contamination amount and pasteurised milk samples used as raw material.

\begin{tabular}{cccc}
\hline MFC samples & $\begin{array}{c}\text { Level of artificial } \\
\text { contamination }\end{array}$ & Milk sample & Bacterial strain \\
\hline Q1 & $10^{2}$ & L1 & RJ581 \\
Q2 & $10^{3}$ & L1 & RJ581 \\
Q3 & $\mathrm{UN}$ & L1 & RJ581 \\
Q4 & $10^{2}$ & L2 & RJ581 \\
Q5 & $10^{3}$ & L2 & RJ581 \\
Q6 & UN & L2 & RJ581 \\
Q7 & $10^{2}$ & L3 & EDL933 \\
Q8 & $10^{3}$ & L3 & EDL933 \\
Q9 & UN & L3 & EDL933 \\
Q10 & $10^{2}$ & L4 & EDL933 \\
Q11 & $10^{3}$ & L4 & EDL933 \\
Q12 & UN & L4 & EDL933 \\
\hline
\end{tabular}

Q: manufactured cheese samples; UN: uncontaminated.

the clot obtained was cut, manually agitated and maintained at $45^{\circ} \mathrm{C}$ for $15 \mathrm{~min}$ until the flakes settled to the bottom of the container. Subsequently, the clot was separated from the whey and placed directly into Minas cheese moulds. The salt $(2.1 \%$; w/v) was added directly into the cheese mass (Furtado, 2005). The cheeses were stored at $8^{\circ} \mathrm{C}$ for up to 15 days in closed plastic. Were prepared twelve MFC, six cheeses for each bacterial strain studied (Table 1).

\subsection{Physicochemical analysis of the cheese}

A physicochemical analysis was performed to verify that the cheese met the minimum identity and quality standards established by Brazilian law (Brasil, 1996, 1997, 2004) with respect to fat and moisture. All analyses were performed in duplicate. The moisture content was determined by the gravimetric method (Brasil, 2006). The fat content was determined by the Gerber method (Brasil, 2006).

\subsection{Microbiological analysis of the cheese}

A microbiological analysis was performed to verify the compliance of the cheese with the standards established by Brazilian law (Brasil, 1996). The assay for Salmonella sp, E. coli and total coliform count were performed as described above for milk samples. For Listeria monocytogenes, $25 \mathrm{~g}$ of the sample was homogenised in $225 \mathrm{~mL}$ of Listeria enrichment broth (Oxoid, United Kingdom) in a homogenizer sample (MK1204, Cap-Lab ${ }^{\circledR}$, São Paulo, Brazil) for $120 \mathrm{sec}$ and incubated at $30^{\circ} \mathrm{C}$ for $24 \mathrm{~h}$. Was transferred $0.1 \mathrm{~mL}$ of the culture to $10 \mathrm{~mL}$ of Fraser broth and incubated at $30{ }^{\circ} \mathrm{C}$ for 24 to $48 \mathrm{~h}$, after than, was transferred to agar Palcam (Oxoid) supplemented with Listeria selective supplement (Oxoid) and incubated at $30^{\circ} \mathrm{C}$ for 24 to $48 \mathrm{~h}$. Staphylococcus aureus in the BPW culture was enumerated by plating $1 \mathrm{~mL}$ of serial dilutions on Petrifilm ${ }^{\mathrm{TM}}$ EC Staph Express (STX) (3M, St. Paul, USA) as recommended by the manufacturer. 
The survival of the O157:H7 strains was evaluated during the MFC processing steps and after 0, 2, 4, 5, 7, 10 and 15 days of storage at $8^{\circ} \mathrm{C}$ (Figure 1$)$.

One hundred microliters of serial dilutions of each sample were plated, in duplicate, on CT-SMAC and incubated for 24 to $48 \mathrm{~h}$ at $35{ }^{\circ} \mathrm{C}$. Colonies typical of E. coli O157, which are non-sorbitol fermenting (clear) with a black point in the centre (tellurite reduction), were counted. After counting, five typical colonies of E. coli O157 were selected and subjected to PCR (polymerase chain reaction) for $r f b 0157$ gene research, this gene encodes for the O157 antigen (Paton \& Paton, 1998). Two replicates of each test were performed.

\subsection{Statistical analyses}

Count data were log transformed for all analyses. To evaluate the behaviour of STEC O157:H7 during the storage of MFC, a linear mixed-effects model was applied to the data. Time (in days) and the combination of strain and level of artificial contamination were used as fixed effects and milk sample as random effect. Contrasts of interests were tested with the use of lme package in R software.

\section{Results and discussion}

\subsection{Milk quality}

Milk quality is defined by determining parameters for chemical, physicochemical and microbiological composition. Acidity is one of the minimum parameters required to demonstrate the quality and identity of pasteurised milk, and this value should be 0.14 to $0.18 \mathrm{~g} \%$ (w/v) of lactic acid (Brasil, 2011). The values determined by this study ranged from 0.17 to $0.18 \mathrm{~g}$ of lactic acid, which is in accordance with the permitted limits. Another important factor in evaluating the milk quality is the presence of antibiotic residues. This type of substance, when present in milk, can confound the results of quality analyses and interfere with the production of milk derivatives (Nascimento et al., 2001). All milk samples used for cheese manufacture had a negative result regarding the presence of antibiotics (Table 2).

To evaluate the microbiological quality of pasteurised milk, the samples were qualitatively assessed for the presence of Salmonella sp and E. coli O157:H7 and quantitatively assessed for E. coli. E. coli O157:H7 was not present in the pasteurised milk prior to the artificial inoculation. The pasteurised milk samples did not show Salmonella sp in $25 \mathrm{~mL}$, which is the threshold established by Brazilian law (Brasil, 1996). However, the number of $E$. coli found as faecal contamination indicator were notably high, with values ranging from $3.5 \mathrm{x}$ $10^{4}$ to $>10^{5}$ CFU.mL ${ }^{-1}$ of milk. Brazilian law does not provide standards for E. coli. However, the maximum allowable count of thermotolerant coliforms at $45^{\circ} \mathrm{C}$ is $4 \mathrm{MPN}$ (most probable number). $\mathrm{mL}^{-1}$ of pasteurised milk. One should consider that among the faecal indicator bacteria, E. coli is the true indicator of this contamination type because it is the only member of the group of coliform bacteria that is exclusively of faecal origin and can provide information on the sanitary conditions of production, processing and storage (International Commission

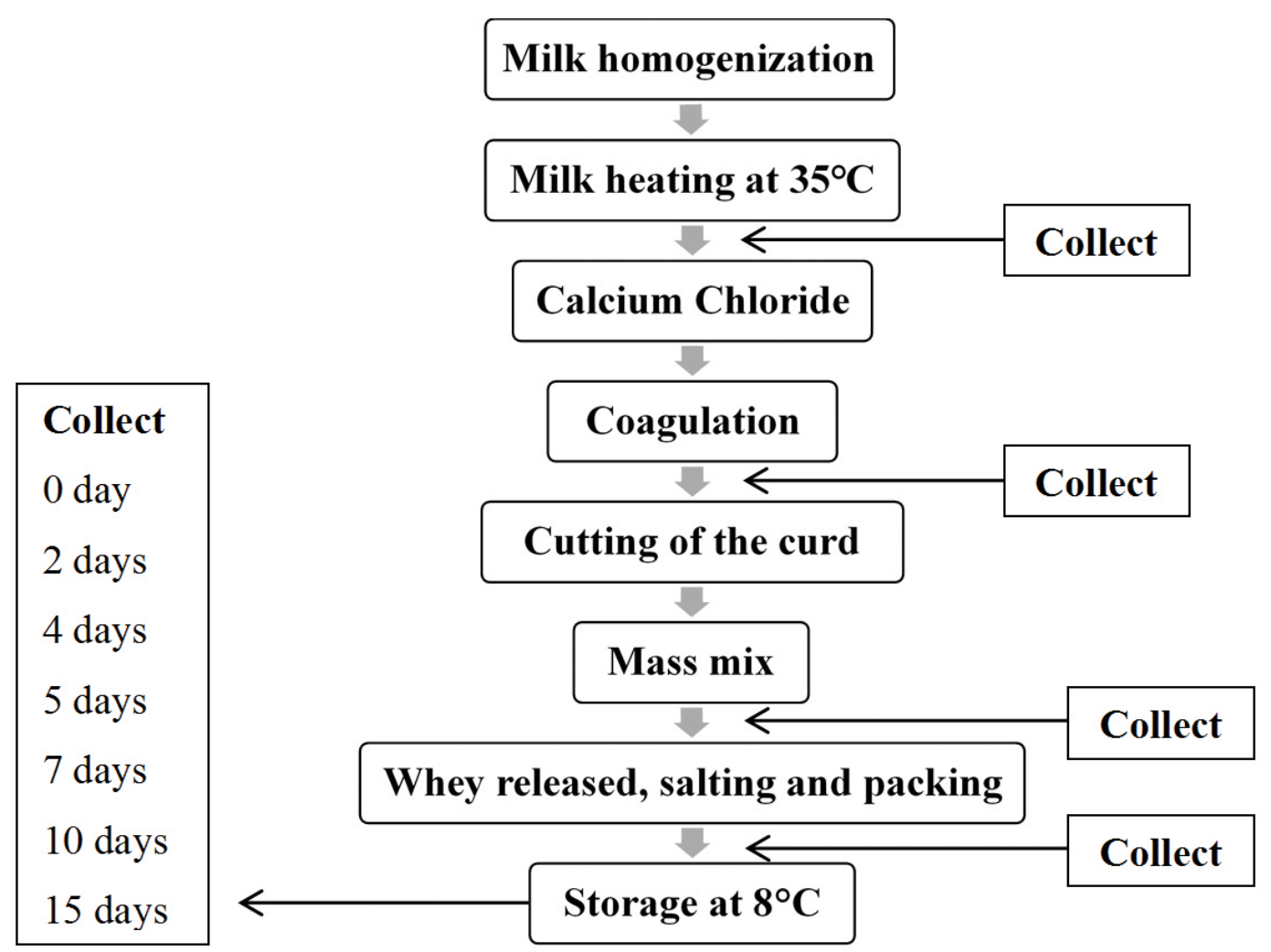

Figure 1. Sample collection points during the process and storage steps of artificially contaminated Minas frescal cheese. 
on Microbiological Specifications for Foods, 1978). E. coli, including pathogenic E. coli, are bacteria commonly found in raw and pasteurised milk produced in Brazil (Ataíde et al., 2008). These results indicate a need for the revision or implementation of hygiene practices and evaluation of the effectiveness of processes adopted by producers in the pasteurisation of milk and more careful selection of suppliers. Despite displaying E. coli above the standards established by Brazilian law, the milk samples were used as raw material for the preparation of MFC, because they were not contaminated with serotype O157:H7.

\subsection{Minas frescal cheese identity and quality}

To verify the identity and quality standards of the MFC, the percentage of fat in dry matter (FDM) and moisture in the control cheese for each test were measured (Table 3 ). The results for the parameters determined for FDM and moisture in the cheeses allowed for samples Q6, Q9 and Q12 to be characterised as MFC based on the standard of identity and quality for this cheese (Brasil, 1997). Sample Q3, because of a higher fat content than the standard of identity and quality (Brasil, 1997), could not be characterised as MFC. Although the Q3 sample did not fall within the standards according to fat content, this parameter was not considered to be an exclusion criterion for this sample because only a relatively small number of microorganisms are able to utilise fat as an energy source, while the moisture content is a crucial parameter for microbial growth and could contribute to a change in the behaviour of the strains studied. Therefore, all samples of cheese were used to evaluate the behaviour of the strains studied.

The microbiological quality of the MFC prepared with pasteurized milk that was artificially contaminated with $10^{2}$ and $10^{3}$ CFU.mL ${ }^{-1}$ of O157:H7 strains EDL 933 and RJ581 was evaluated by comparing the results of the samples with the values established by Brazilian law (Brasil, 1996) (Table 4).

All of the MFC samples produced were in accordance with the standards established by legislation (Brasil, 1996) for Salmonella and L. monocytogenes. The Brazilian legislation (Brasil, 1996) established the standard for Staphylococcus as

Table 2. Physicochemical and microbiological parameters of the pasteurised milk samples used as raw material.

\begin{tabular}{|c|c|c|c|c|}
\hline \multirow{2}{*}{ Parameters } & \multicolumn{4}{|c|}{ Milk samples } \\
\hline & L1 & $\mathrm{L} 2$ & L3 & L4 \\
\hline Total acidity & 0.18 & 0.17 & 0.17 & 0.17 \\
\hline Antibiotics residue & negative & negative & negative & negative \\
\hline E. coli $\left(\mathrm{CFU} \cdot \mathrm{mL}^{-1}\right)$ & $10^{5}$ & $10^{5}$ & $1.7 \times 10^{5}$ & $3.5 \times 10^{4}$ \\
\hline Salmonella sp. $25 \mathrm{~mL}^{-1}$ & absent & absent & absent & absent \\
\hline E. coli $\mathrm{O} 157: \mathrm{H}_{7} \cdot \mathrm{mL}^{-1}$ & absent & absent & absent & absent \\
\hline
\end{tabular}

L: pasteurized milk; L1: milk used in the preparation of the Q1, Q2 and Q3 samples; L2: milk used in the preparation of the Q4, Q5 and Q6 samples; L3: milk used in the preparation of the Q7, Q8 and Q9 samples; L4: milk used in the preparation of the Q10, Q11 and Q12 samples. ${ }^{\mathrm{g}} \%$ of lactic acid.mL ${ }^{-1}$.

Table 3. Physicochemical quality assessment of the Minas frescal cheese (MFC) uninoculated studied.

\begin{tabular}{lccccc}
\hline \multirow{2}{*}{ Parameters (g\%) } & \multicolumn{3}{c}{ MFC Samples } & Q12 & \multirow{2}{*}{ Standard $^{\mathrm{b}}$} \\
\cline { 2 - 5 } & Q3 & Q6 & Q9 & 44.13 & $25-44.9 \%$ \\
FDM $^{\mathrm{a}}$ & 53.70 & 41.84 & 44.53 & 69.86 & $>55 \%$ \\
Moisture & 60.65 & 59.36 & 66.32 & 69 & \\
\hline
\end{tabular}

Q: manufactured cheese samples; ${ }^{\text {fat }}$ in dry matter; ${ }^{\mathrm{b} B r a z i l i a n}$ law (Brasil, 1996).

Table 4. Microbiological quality of Minas frescal cheese (MFC).

\begin{tabular}{ccccc}
\hline \multirow{2}{*}{ MFC samples } & \multicolumn{3}{c}{ Parameters } \\
\cline { 2 - 5 } Salmonella sp $^{\mathrm{b}}$ & L. monocytogenes $^{\mathrm{b}}$ & S. aureus $^{\mathrm{c}}$ & $<$. coli $^{\mathrm{c}}$ \\
\hline Q1 & absent & absent & $<10$ & $<1.29 \times 10^{7}$ \\
Q2 & absent & absent & $<10$ & $1.4 \times 10^{6}$ \\
Q3 & absent & absent & $<10$ & $9.2 \times 10^{6}$ \\
Q4 & absent & absent & $<10$ & $1.2 \times 10^{7}$ \\
Q5 & absent & absent & $<10$ & $1.4 \times 10^{7}$ \\
Q6 & absent & absent & $<10$ & $1.9 \times 10^{7}$ \\
Q7 & absent & absent & $<10$ & $3.0 \times 10^{6}$ \\
Q8 & absent & absent & $<10$ & $5.2 \times 10^{6}$ \\
Q9 & absent & absent & $<10$ & $9.5 \times 10^{5}$ \\
Q10 & absent & absent & $<10$ & $1.3 \times 10^{5}$ \\
Q11 & absent & absent & $<10$ & $4.5 \times 10^{5}$ \\
Q12 & absent & absent & $1.0 \times 10^{3}$ & $5.0 \times 10^{5}$ \\
Standard $^{\text {a }}$ & absent & absent & $5.0 \times 10^{2}$ \\
\hline
\end{tabular}

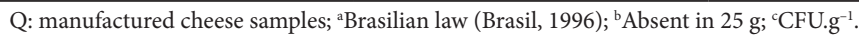


coagulase-positive. However, the research was performed in S. aureus (a representative of the category), and there were $<10 \mathrm{CFU}$ of this microorganism per $\mathrm{g}$ of cheese. The E. coli faecal contamination indicator showed counts of up to $5.2 \times 10^{6} \mathrm{CFU} . \mathrm{g}^{-1}$. These high values for $E$. coli may be related to the quality of the raw material used, because a large number of bacteria in all of the samples of pasteurised milk were observed.

\subsection{Search of STEC O157:H7}

In the samples collected during the processing of cheese that was artificially contaminated with $10^{2}$ cells of E. coli O157:H7. $\mathrm{mL}^{-1}$ of milk, it was not possible to count the bacteria through this methodology with the exception of the sample artificially contaminated with the EDL933 strain that was collected after heating at $35^{\circ} \mathrm{C}$ (Table 5). However, after enrichment, E. coli O157:H7 cells were recovered from the samples, indicating the presence of viable cells. The high values for $E$. coli faecal contamination indicator may have affected the isolation of $E$. coli O157:H7 from the artificially contaminated cheeses with an initial contamination of $10^{2}$ cells. $\mathrm{mL}^{-1}$ of milk was used.

During the manufacturing of MFC with milk artificially contaminated with $10^{3} \mathrm{CFU}$ of E. coli $\mathrm{O} 157: \mathrm{H} 7 \cdot \mathrm{mL}^{-1}$, it was possible to perform bacterial counts on all of the samples, and an increase in the bacterial population of $1 \log$ in the early stages and $2 \log$ in the cheese-ready stage was observed (Table 5). All typical colonies of E. coli O157 in CT-SMAC, subjected to PCR, showed the sequence of $259 \mathrm{bp}$, confirming the presence of the $r f b \mathrm{O} 157$ gene. These results demonstrate that the processing steps do not interfere significantly with the growth of either E. coli O157:H7 strain.

Sata et al. (1999) reported that the direct detection of E. coli O157:H7 using the conventional procedure of direct plating has a sensitivity of $10^{2}$ to $10^{4} \mathrm{CFU} . \mathrm{g}^{-1}$ or $\mathrm{mL}^{-1}$, depending on the food. Simple plating on CT-SMAC has low sensitivity because this medium is not suitable for the detection of stressed cells (McCarthy et al., 1998). In cheese, the bacterial cells are commonly stressed, mainly due to the presence of lactic acid (Jordan \& Maher, 2006). Jordan \& Maher (2006) reported that the detection limit of E. coli O157:H7 from food using CT-SMAC is approximately $10^{3}$ CFU.g ${ }^{-1}$. This finding could explain the lack of detection of STEC O157:H7 in certain evaluations in this study. To increase the detection sensitivity for E. coli O157:H7 in food by CT-SMAC, an enrichment step is required (Zadik et al., 1993). However, this step increases the bacterial population and does not portray the real number of bacteria in the original product. Saad \& Franco (1999) assessed the influence of the natural microbiota of raw meat on the growth of $E$. coli O157:H7 in ground beef, which was maintained at $8.5^{\circ} \mathrm{C}$ for $96 \mathrm{~h}$. When intermediate levels of $10^{3}$ to $10^{4} \mathrm{CFU} . \mathrm{g}^{-1}$ of $\mathrm{E}$. coli $\mathrm{O} 157: \mathrm{H} 7$ were incubated with $10^{6}$ to $10^{7} \mathrm{CFU} . \mathrm{g}^{-1}$ of non-pathogenic E. coli, it was only possible to count E. coli $\mathrm{O} 157: \mathrm{H} 7$ up to $24 \mathrm{~h}$ of storage at $8.5^{\circ} \mathrm{C}$, and this count was equal to the initial contamination level, which most likely was observed due to the difficulty of enumerating the pathogen in the midst of high counts of non-pathogenic E. coli. When the contamination level was smaller, i.e., from $10^{1}$ to $10^{2} \mathrm{CFU} \cdot \mathrm{g}^{-1}$, the difficulties increased, and it was not possible count the pathogenic $E$. coli. A higher contamination level of E. coli $\mathrm{O} 157: \mathrm{H} 7,10^{6}$ to $10^{7} \mathrm{CFU}^{-1}{ }^{-1}$, mixed with nonpathogenic E. coli did not affect the growth and counting of the pathogen. After artificially contaminating cheddar and Gouda cheese with 20 CFU.g ${ }^{-1}$, D'Amico et al. (2010) did not observe E. coli $\mathrm{O} 157: \mathrm{H} 7$ colonies by direct plating in approximately half of the analyses because there was an overgrowth of the natural microbiota of the cheese.

Thus, the results confirm that lower levels of initial contamination with E. coli O157:H7, such as $10^{2} \mathrm{CFU} \cdot \mathrm{mL}^{-1}$, influence the detection of the pathogen. It is possible that the high numbers of $E$. coli found by the faecal contamination indicator may have interfered with the development and/or detection of the pathogen. There was no significant difference in the behaviour of the different E. coli O157:H7 strains evaluated during the processing steps for MFC. The process did not affect the growth and/or viability of the pathogen.

Although this work did not aim to evaluate the sensitivity of the detection method, the results show that direct counting on CT-SMAC exhibited a low level of sensitivity.

The results for each group were compared to identify differences with respect to the time of storage at $8{ }^{\circ} \mathrm{C}$, artificial initial contamination level and bacterial strains. Results obtained after adjusting a linear mixed-effects model indicated no significant difference between the contamination levels $\left(10^{2}\right.$ and $\left.10^{3}\right)$ across time. After evaluating differences from baseline (day 0 ) it was detected a significant increase in the E. coli $\mathrm{O} 157: \mathrm{H7}$ population on days 4 and 5 and, after that the population declined $(\mathrm{p}<0.05)$. A significant decrease, compared to baseline, occured on days 10 and $15(\mathrm{p}<0.05)$. There were no significant differences between strains EDL933 and RJ581 when considering the whole time course .

The storage temperature of $8{ }^{\circ} \mathrm{C}$ allowed for the growth of E. coli O157:H7 in MFC until the 4th or 5th day of the storage period, after which there was a reduction in the bacterial

Table 5. Counts of E. coli O157:H7 (CFU.g $\left.{ }^{-1}\right)$ during the manufacturing steps of Minas frescal cheese.

\begin{tabular}{|c|c|c|c|c|}
\hline \multirow{3}{*}{ Collection points } & \multicolumn{4}{|c|}{ Artificial contamination level of bacterial strains } \\
\hline & RJ581 & & EDL933 & \\
\hline & $10^{2}$ & $10^{3}$ & $10^{2}$ & $10^{3}$ \\
\hline After heating to $35^{\circ} \mathrm{C}$ & $<10^{2}$ & $5.5 \times 10^{4}$ & $9.0 \times 10^{2}$ & $5.8 \times 10^{4}$ \\
\hline After salting and stirring at $42{ }^{\circ} \mathrm{C}$ & $<10^{2}$ & $1.1 \times 10^{4}$ & $<10^{2}$ & $2.3 \times 10^{4}$ \\
\hline Cheese & $<10^{2}$ & $4.7 \times 10^{4}$ & $<10^{2}$ & $1.2 \times 10^{5}$ \\
\hline
\end{tabular}



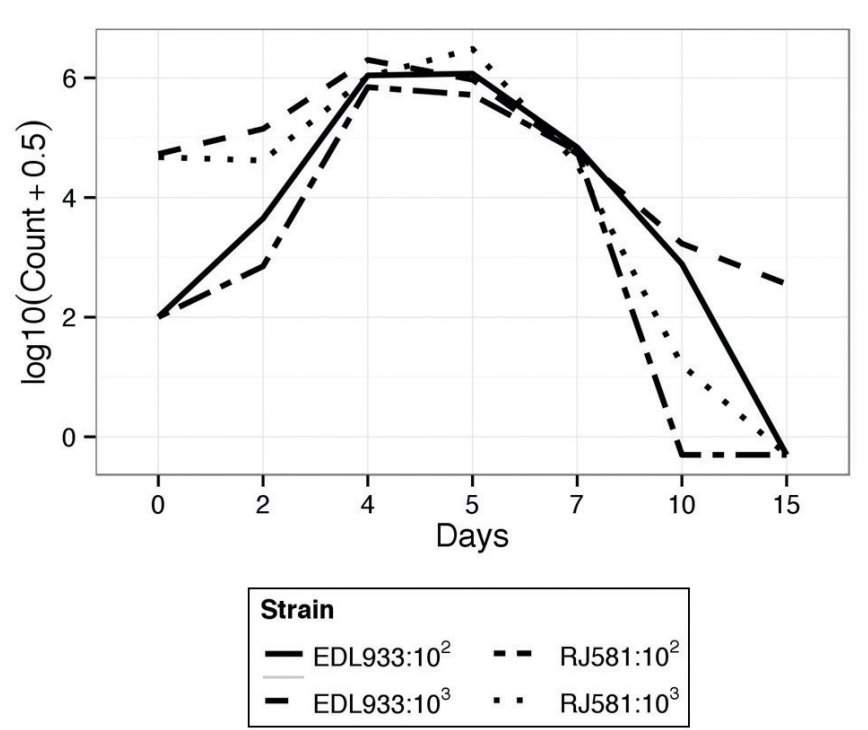

Figure 2. Behaviour of E. coli O157:H7 during storage at $8{ }^{\circ} \mathrm{C}$.

population. In addition, viable cells were found until at the least the 7th and 10th storage day in the MFC manufactured with artificial initial contaminations level of $10^{2}$ and $10^{3} \mathrm{CFU} \cdot \mathrm{mL}^{-1}$ of milk, respectively (Figure 2). This suggests a psychrotrophic behavior of the O157: H7 strains studied.

Marek et al. (2004), who evaluated the behaviour of mixed E. coli $\mathrm{O} 157: \mathrm{H} 7$ strains (initial concentration of $10^{2}$ and $10^{5}$ cells. $\mathrm{mL}^{-1}$ ) in pasteurised and unpasteurised Cheddar cheese whey stored at temperatures of 4,10 and $15^{\circ} \mathrm{C}$ for 28 days, obtained similar results to those of this study. At the storage temperatures of 10 and $15^{\circ} \mathrm{C}$, regardless of the artificial initial contamination level, the numbers of E. coli O157:H7 had a significant increase on days 7 and 4 of storage, respectively, and a decline in their population was observed soon after. Other authors have also described the multiplication and survival of $E$. coli $\mathrm{O} 157: \mathrm{H} 7$ at low temperatures (Ramsaran et al., 1998).

The interest of STEC in the food safety from animal origin, appeared with increasing number of human infections caused by this pathogen (Hussein \& Sakuma, 2005). The survival of STEC O157:H7 in different types of cheese have already been demonstrated (Marek et al., 2004; D’Amico et al., 2010), but there are no reports on MFC, a not matured cheese with great commercial importance in Brazil.

The low infectious dose showed by STEC O157:H7, together with the feasibility of survival in MFC, allows us to include this food as a potential public health problem, since the Brazilian cattle is an important reservoir of STEC. And studies in the literature show the high contamination of the MFC by E. coli (Araújo et al., 2002). However, the expression of virulence within the cheese matrix may be altered over time by prolonged exposure to salt, acid, low temperatures, low moisture, and the presence of starter culture (D’Amico et al., 2010). Perhaps, this can be included with other explanations for the low incidence of the STEC diseases, including serotype O157:H7, in Brazil.

Due the high frequency of STEC in cattle from different regions of Brazil (Cerqueira et al., 1999; Irino et al., 2005), was considered the MFC as a potential vehicle for transmission of STEC, because the conditions as the raw material, processing, transport and storage may allow contamination of this type of cheese by these bacteria, which has been demonstrated even in countries with better sanitary standards (Vernozy-Rozand et al., 2005).

Because of the variation in host susceptibility, a number of individuals exposed to cheeses contaminated with STEC O157:H7 may develop mild forms of illness that go unreported (D’Amico et al., 2010).

\section{Conclusions}

The processing of MFC does not eliminate STEC O157:H7 and the detection of viable cells at all stages of processing are possible.

The different E. coli O157:H7 strains studied showed the same behavioural profile under various conditions. Due his psychrotrophic behaviour, the temperature of $8{ }^{\circ} \mathrm{C}$ cannot be used to control the growth of E. coli O157:H7. E. coli O157:H7 requires a low infectious dose of fewer than 100 cells. $\mathrm{g}^{-1} \mathrm{or} \mathrm{mL}^{-1}$ of food. As a result, the capacity of this bacterium to remain viable during processing and storage of MFC is high, and special attention should be directed to this food. MFC is a potential vehicle for STEC O157:H7, which makes this food a problem, given the poor hygiene conditions of these products in the domestic market and in food processing. More studies should be conducted, including an assessment of the microflora present in the viability of the STEC O157:H7.

\section{Acknowledgements}

This study was supported by grants from CAPES awarded to Jesieli Braz Frozi and FAPERJ and FOPESQ/UFF for the financial support.

\section{References}

American Public Health Association - APHA. (2001). Compendium of methods for the microbiological examination of foods. 4th ed. Washington: Frances Pouch Downes Keith Ito.

Araújo, V. S., Pagliares, V. A., Queiroz, M. L. P., \& Freitas-Almeida, A. C. (2002). Occurrence of Staphylococcus and enteropathogens in soft cheese commercialized in the city of Rio de Janeiro, Brazil. Journal of Applied Microbiology, 92(6), 1172-1177. http://dx.doi. org/10.1046/j.1365-2672.2002.01656.x. PMid:12010558

Ataíde, W. S., Maciel, J. F., Lima, A. L. P., Lima, A. R. C., Silva, F. V. G., \& Silva, J. A. (2008). Avaliação microbiológica e físico-química durante o processamento do leite pasteurizado. Revista do Instituto Adolfo Lutz, 67(1), 73-77.

Brasil, Ministério da Agricultura Pecuária e Abastecimento. (1996). Aprova o Regulamento Técnico de Identidade e Qualidade de Produtos Lácteos (Portaria no 146, de 7 de março de 2010). Diário Oficial da República Federativa do Brasil.

Brasil, Ministério da Agricultura Pecuária e Abastecimento. (1997). Aprova o Regulamento Técnico para Fixação de Qualidade e Identidade de Queijo Minas Frescal (Portaria no 352, de 4 de setembro de 1997). Diário Oficial da República Federativa do Brasil. 
Brasil, Ministério da Agricultura Pecuária e Abastecimento. (2004). Inclui o termo "Muito" na expressão "Alta Umidade" nos itens 2.2 (Classificação), 4.2.3 (Requisitos Físico-químicos) e 5.1 (Aditivos), no Regulamento Técnico para Fixação de Identidade e Qualidade do Queijo Minas Frescal (Instrução Normativa no 04, de 01 de março de 2004). Diário Oficial da República Federativa do Brasil.

Brasil, Ministério da Agricultura Pecuária e Abastecimento. (2006). Oficializa os Métodos Analíticos Oficiais Físico-Químicos, para Controle de Leite e Produtos Lácteos (Instrução Normativa $n^{\circ}$ 68, de 12 de dezembro de 2006). Diário Oficial da República Federativa do Brasil.

Brasil, Ministério da Agricultura Pecuária e Abastecimento. (2011). Aprovar o Regulamento Técnico de Produção, Identidade e Qualidade do Leite tipo A, o Regulamento Técnico de Identidade e Qualidade de Leite Cru Refrigerado, o Regulamento Técnico de Identidade e Qualidade de Leite Pasteurizado e o Regulamento Técnico da Coleta de Leite Cru Refrigerado e seu Transporte a Granel (Instrução Normativa $n^{\circ}$ 62, de 29 de dezembro de 2011). Diário Oficial da República Federativa do Brasil.

Breidt Junior, F., \& Caldwell, J. M. (2011). Survival of Escherichia coli O157:H7 in cucumber fermentation brines. Journal of Food Science, 76(3), M198-M203. http://dx.doi.org/10.1111/j.17503841.2011.02045.x. PMid:21535844

Centers for Disease Control and Prevention - CDC. (2000). Outbreak of Escherichia coli O157:H7 infection associated with eating fresh cheese curds-Wisconsin, June 1998. Journal of the American Medical Association, 284(23), 2991-2992. http://dx.doi.org/10.1001/ jama.284.23.2991. PMid:11188067

Cerqueira, A. M. F., Guth, B. E. C., Joaquim, R. M., \& Andrade, J. R. C. (1999). High occurrence of Shiga toxin-producing Escherichia coli (STEC) in healthy cattle in Rio de Janeiro State, Brazil. Veterinary Microbiology, 70(1-2), 111-121. http://dx.doi.org/10.1016/S03781135(99)00123-6. PMid:10591502

D’Amico, D. J., Druart, M. J., \& Donnelly, C. W. (2010). Behavior of Escherichia coli O157:H7 during the manufacture and aging of Gouda and stirred-curd Cheddar cheeses manufactured from raw milk. Journal of Food Protection, 73(12), 2217-2224. PMid:21219739.

Furtado, M. M. (2005). Principais problemas dos queijos: causas e prevenção. São Paulo: Fonte Comunicação e Editora.

Goh, S., Newman, C., Knowles, M., Bolton, F. J., Hollyoak, V., Richards, S., Daley, P., Counter, D., Smith, H. R., \& Keppie, N. (2002). E. coli O157 phage type 21/28 outbreak in North Cumbria associated with pasteurized milk. Epidemiology and Infection, 129(3), 451-457. http://dx.doi.org/10.1017/S0950268802007835. PMid:12558327

Guth, B. E. C., Lopes de Souza, R., Vaz, T. M. I., \& Irino, K. (2002). First Shiga toxin-producing Escherichia coli isolate from a patient with hemolytic uremic syndrome, Brazil. Emerging Infectious Diseases, 8(5), 535-536. http://dx.doi.org/10.3201/eid0805.010419. PMid:11996695

Hussein, H. S., \& Sakuma, T. (2005). Prevalence of shiga toxinproducing Escherichia coli in dairy cattle and their products. Journal of Dairy Science, 88(2), 450-465. http://dx.doi.org/10.3168/ jds.S0022-0302(05)72706-5. PMid:15653509

International Commission on Microbiological Specifications for Foods - ICMSF. (1978). Microorganisms in foods 1: their significance and methods of enumeration. 2nd ed. Toronto: University of Toronto Press.

Irino, K., Kato, M. A. M. F., Vaz, T. M. I., Ramos, I. I., Souza, M. A., Cruz, A. S., Gomes, T. A., Vieira, M. A., \& Guth, B. E. (2005). Serotypes and virulence markers of Shiga toxin-producing Escherichia coli (STEC) isolated from dairy cattle in São Paulo State, Brazil.
Veterinary Microbiology, 105(1), 29-36. http://dx.doi.org/10.1016/j. vetmic.2004.08.007. PMid:15607081

Jordan, K. N., \& Maher, M. M. (2006). Sensitive detection of Escherichia coli O157:H7 by conventional plating techniques. Journal of Food Protection, 69(3), 689-692. PMid:16541707.

Lim, J. Y., Li, J., Sheng, H., Besser, T. E., Potter, K., \& Hovde, C. J. (2007). Escherichia coli O157:H7 colonization at the rectoanal junction of long-duration culture-positive cattle. Applied and Environmental Microbiology, 73(4), 1380-1382. http://dx.doi.org/10.1128/ AEM.02242-06. PMid:17189448

Marek, P., Nair, M. K., Hoagland, T., \& Venkitanarayanan, K. (2004). Survival and growth characteristics of Escherichia coli O157:H7 in pasteurized and unpasteurized Cheddar cheese whey. International Journal of Food Microbiology, 94(1), 1-7. http://dx.doi.org/10.1016/ S0168-1605(03)00331-3. PMid:15172479

McCarthy, J., Holbrook, R., \& Stephens, P. J. (1998). An improved direct plate method for the enumeration of stressed Escherichia coli O157:H7 in food. Journal of Food Protection, 61(9), 1093-1097. PMid:9766057.

Nascimento, G. G. F., Maestro, V., \& Campos, M. S. P. (2001). Occurrence of antibiotic residues in milk marketed in Piracicaba, SP, Brazil. The Journal of Nutrition, 14(2), 119-124.

Paton, A. W., \& Paton, J. C. (1998). Detection and characterization of Shiga toxigenic Escherichia coli by using multiplex PCR assays for stx1, stx2, eaeA, enterohemorrhagic E. coli hlyA, rfbO111, and rfbO157. Journal of Clinical Microbiology, 36(2), 598-602. PMid:9466788.

Ramsaran, H., Chen, J., Brunke, B., Hill, A., \& Griffiths, M. W. (1998). Survival of bioluminescent Listeria monocytogenes and Escherichia coli O157:H7 in soft cheeses. Journal Dairy Science, 81(7), 18101817.

Riley, L. W., Remis, R. S., Helgerson, S. D., McGree, H. B., Wells, J. G., Davis, B. R., Herbert, R.J., Olcott, E. S., Johnson, L. M., Hargrett, N. T., Blake, P. A., \& Cohen, M. L. (1983). Hemorragic colitis associated with a rare Escherichia coli serotype. The New England Journal of Medicine, 308(12), 681-685.

Saad, S. M. I., \& Franco, B. D. G. M. (1999). Influence of raw meat natural background flora on growth of Escherichia coli O157:H7 in ground beef. Journal of the Brazilian Society for Microbiology, 30(3), 272-277.

Sata, S., Osawa, R., Furukawa, I., \& Yamai, S. (1999). [A comparison of sensitivity between direct plate culture, immunomagnetic separation and polymerase chain reaction for the isolation of enterohemorrhagic Escherichia coli O157]. Japanese Journal of Bacteriology, 54(3), 659-665. http://dx.doi.org/10.3412/jsb.54.659. PMid:10502952

Souza, R. L., Abreu Carvalhaes, J. T., Sanae Nishimura, L., de Andrade, M. C., \& Cabilio Guth, B. E. (2011). Hemolytic uremic syndrome in pediatric intensive care units in São Paulo, Brazil. The Open Microbiology Journal, 5, 76-82. http://dx.doi.org/10.2174/1874285 801105010076. PMid:21804902

Vernozy-Rozand, C., Mazuy-Cruchaudet, C., Bavai, C., Montet, M. P., Bonin, V., Dernburg, A., \& Richard, Y. (2005). Growth and survival of Escherichia coli O157:H7 during the manufacture and ripening of raw goat milk lactic cheeses. International Journal of Food Microbiology, 105(1), 83-88. http://dx.doi.org/10.1016/j. ijfoodmicro.2005.05.005. PMid:16055219

Zadik, P. M., Chapman, P. A., \& Siddons, C. A. (1993). Use of tellurite for the selection of verocytotoxigenic Escherichia coli O157. Journal of Medical Microbiology, 39(2), 155-158. http://dx.doi. org/10.1099/00222615-39-2-155. PMid:8345511 